\title{
Effect of ytterbium oxide co-doping impurity on the structure and transport characteristics of $\left(\mathrm{ZrO}_{2}\right)_{0.91-\mathrm{x}}\left(\mathrm{Sc}_{2} \mathrm{O}_{3}\right)_{0.09}\left(\mathrm{Yb}_{2} \mathrm{O}_{3}\right)_{\mathrm{x}}(\mathrm{x}=0$ - 0.01) single crystals
}

M.A. Borik ${ }^{1}$, G.M. Korableva ${ }^{2}$, A.V. Kulebyakin ${ }^{1,}{ }^{*}$, I.E. Kuritsyna ${ }^{2}$, E.E. Lomonova ${ }^{1}$, V.A. Myzina ${ }^{1}$, P.A. Ryabochkina ${ }^{3}$, N.V. Sidorova ${ }^{3}$, N.Yu. Tabachkova ${ }^{1,4}$ and T.V. Volkova ${ }^{3}$

${ }^{1}$ Prokhorov General Physics Institute of the Russian Academy of Sciences, Moscow, Russia;

${ }^{2}$ Institute of Solid State Physics of the Russian Academy of Sciences, Chernogolovka, Russia;

${ }^{3}$ Ogarev Mordovia State University, Saransk, Russia;

${ }^{4}$ National University of Science and Technology «MISIS», Moscow, Russia.

* Corresponding author: kulebyakin@lst.gpi.ru 


\section{INTRODUCTION}

Materials based on zirconia are a promising electrolyte for an application in solid oxide fuel cells (SOFC) that can operate at $1100 \mathrm{~K}$. Scandia stabilized zirconia (ScSZ) have the highest conductivity at moderate temperatures. However, a major disadvantage of these materials is the degradation of their conductivity during long-term operation due to an unstable phase composition. Partial replacement of scandia for other oxides in the $\mathrm{ZrO}_{2}-\mathrm{Sc}_{2} \mathrm{O}_{3}$ system aimed at increasing the stability of the highconductivity cubic phase proves to be one of the most efficient solutions to these problems.

The aim of this work is to assess the effect of the introduction of dopant ytterbium oxide into $\mathrm{ZrO}_{2}$ -9 mol.\% $\mathrm{Sc}_{2} \mathrm{O}_{3}$ solid solutions on the phase composition, structure, and electrophysical properties of the material.
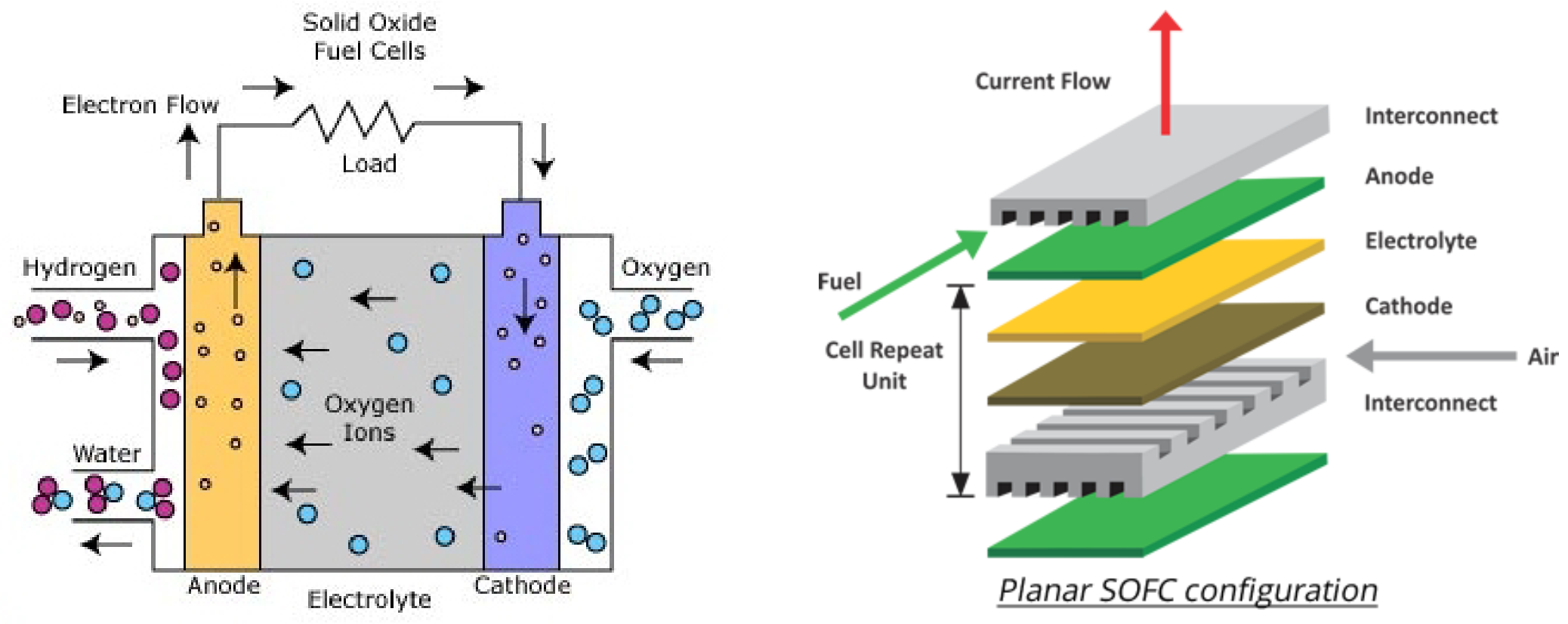


\section{The three zirconia polymorphs}
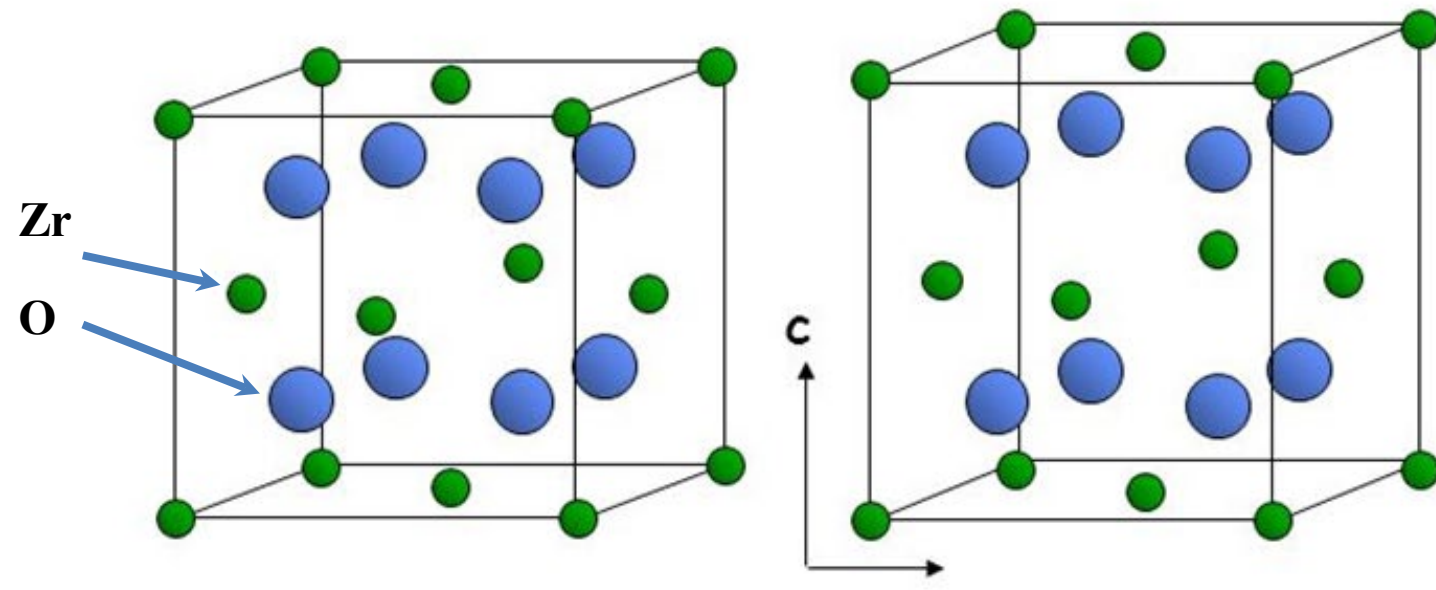

cubic $c$-phase $\mathrm{ZrO}_{2}$ $\mathrm{Fm} 3 \mathrm{~m}$

$2680-2370{ }^{\circ} \mathrm{C}$

$\mathrm{a}=\mathrm{b}=\mathrm{c}$

$\alpha=\beta=\gamma=90^{\circ}$ a

tetragonal $t$-phase

$$
\mathrm{P}_{2} / \mathrm{nmc}
$$

$2370-1160{ }^{\circ} \mathrm{C}$

$\mathrm{a}=\mathrm{b} \neq \mathrm{c}$

$\alpha=\beta=\gamma=90^{\circ}$

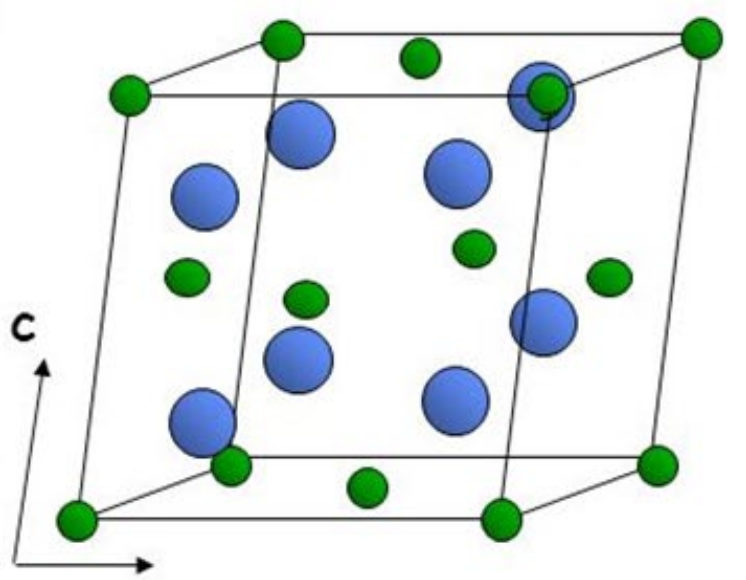

a

monoclinic $m$-phase

$\mathrm{P} 2_{1} / \mathrm{C}$

$<1160^{\circ} \mathrm{C}$

$\mathrm{a} \neq \mathrm{b} \neq \mathrm{c}$

$\alpha=\gamma=90^{\circ} \quad \beta>90^{\circ}$

Crystals of the monoclinic phase of zirconia are needle-shaped and very small, so they do not find practical application.

The tetragonal and cubic phases are of interest!

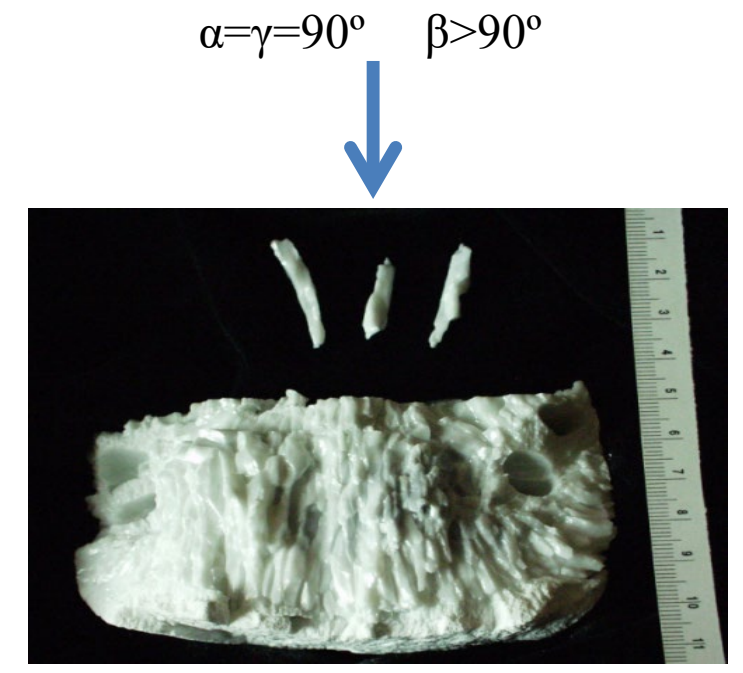




\section{Stabilization of high-temperature zirconia phases}

The cubic and tetragonal phases can be stabilized by doping with $\mathrm{Y}_{2} \mathrm{O}_{3}, \mathrm{Sc}_{2} \mathrm{O}_{3}, \mathrm{CeO}_{2} \ldots$

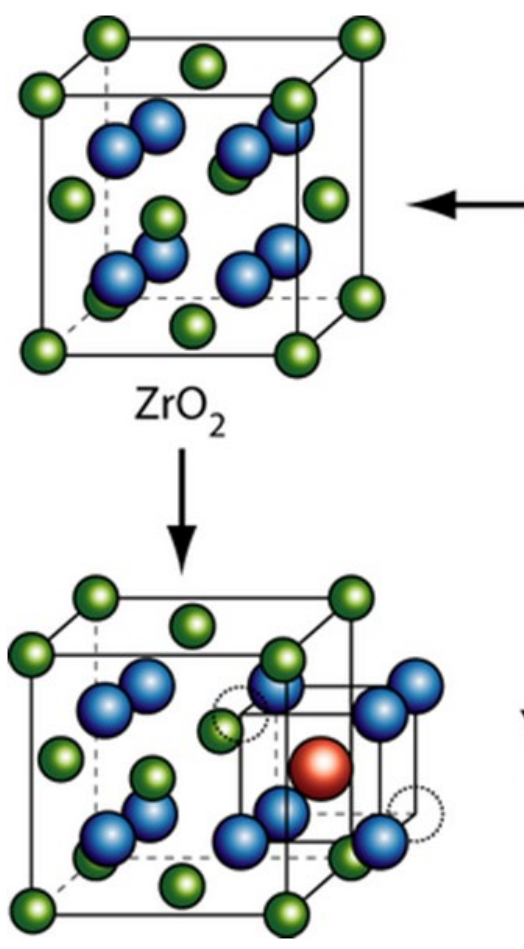

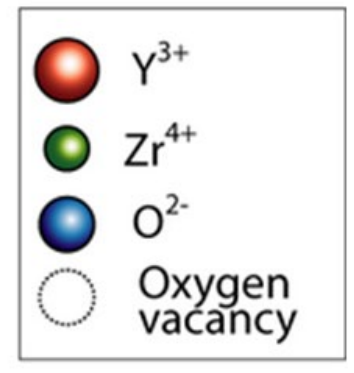

\section{Phase diagram of the zirconia rich portion of $\mathrm{ZrO}_{2}-\mathrm{Y}_{3} \mathrm{O}_{3}$ system [1]}

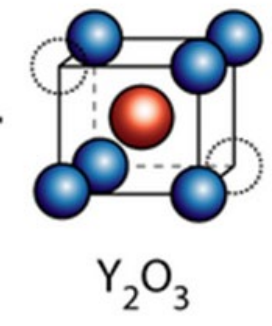

YSZ (Yttria-Stabilised Zirconia) ${ }^{t},{ }^{\circ} \mathrm{C}$

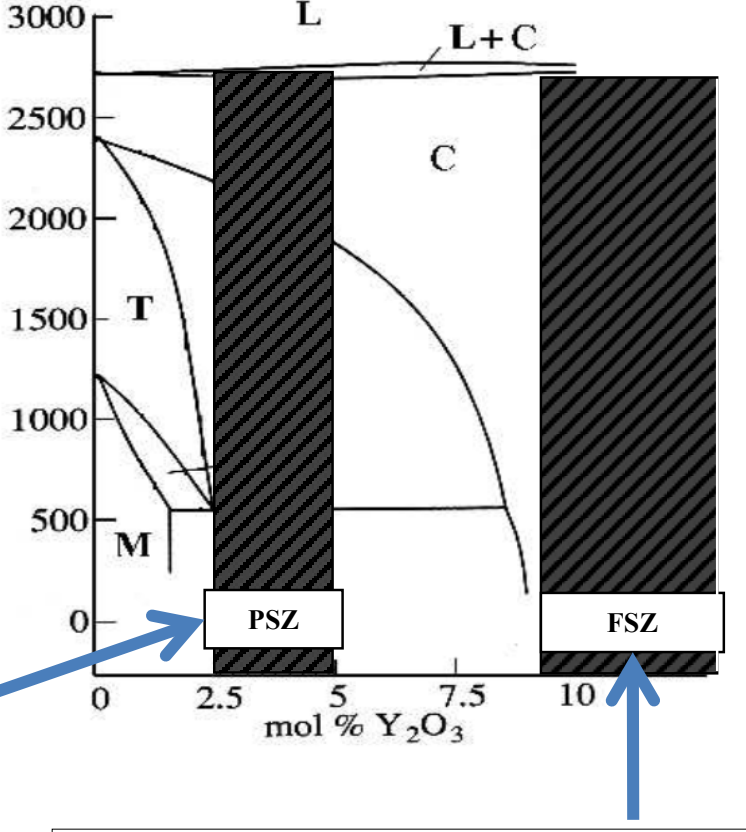

$\mathrm{ZrO}_{2}-(2.5-5)$ mol. $\% \mathrm{Y}_{2} \mathrm{O}_{3}$ Partially Stabilized Zirconia (PSZ) tetragonal phase
$\mathrm{ZrO}_{2}-(9-40) \mathrm{mol}_{2} \% \mathrm{Y}_{2} \mathrm{O}_{3}$

Fully Stabilized Zirconia (FSZ) cubic phase 


\section{Crystal synthesis technology}

The crystals were grown by directional crystallization technique with direct high-frequency heating in a cold container (skull melting)

\footnotetext{
The main advantages of this

method of synthesis :

No temperature limits (up to $\left.3000^{\circ} \mathrm{C}\right)$

No contact with crucible material

No requirements for the particle size distribution of raw materials

The possibility of re-melting crystalline waste
}
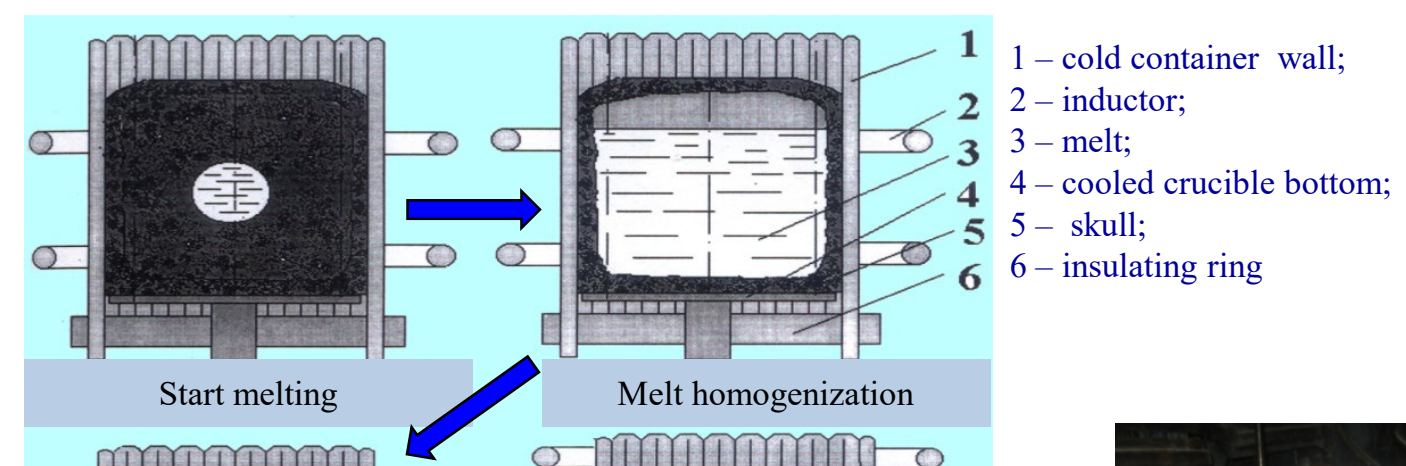

Melt homogenization
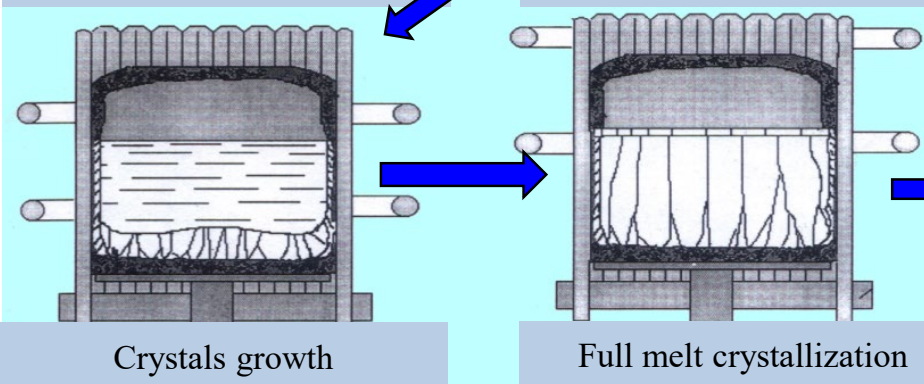

Full melt crystallization

The "Kristall-407" installation

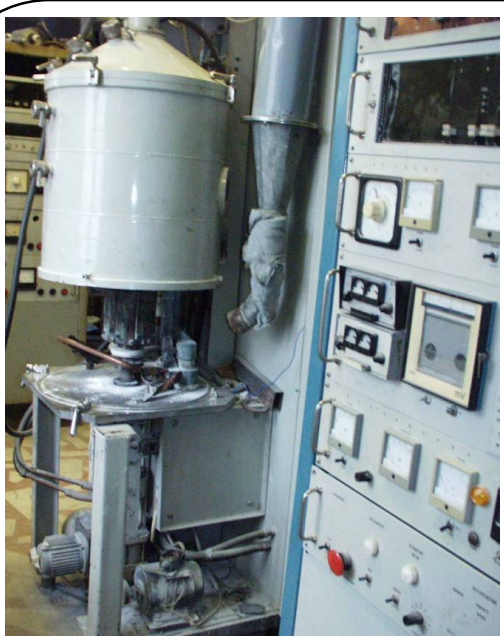

\begin{tabular}{|c|c|}
\hline Electric power & $60 \mathrm{~kW}$ \\
\hline Electromagnetic field frequency & $5.28 \mathrm{MHz}$ \\
\hline Container diameter & $130 \mathrm{~mm}$ \\
\hline Mass of melt & $4-6 \mathrm{~kg}$ \\
\hline Working atmosphere & air \\
\hline
\end{tabular}

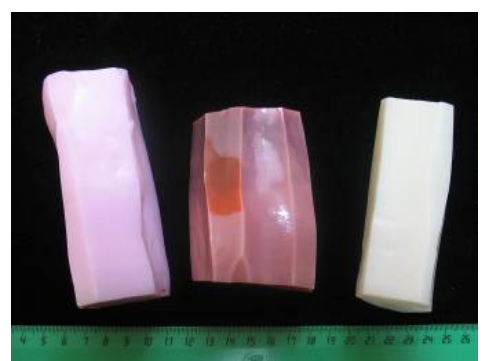

The separation of the bulk into individual crystals
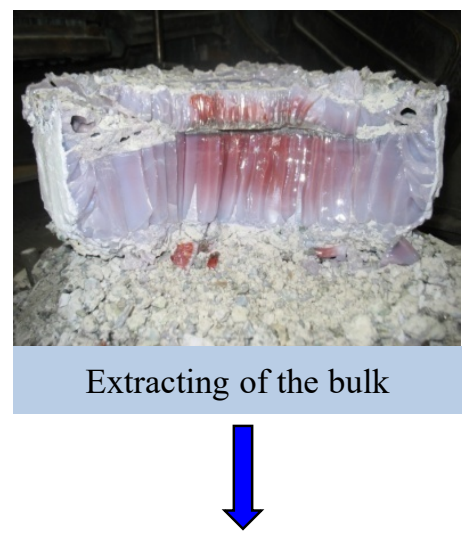


\section{Growth installations for the synthesis of the crystals}

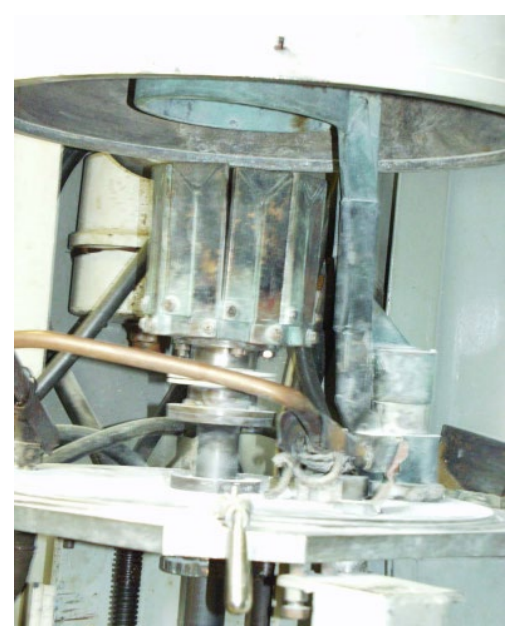

$A$ view of cold container (CC) of $130 \mathrm{~mm}$ diameter

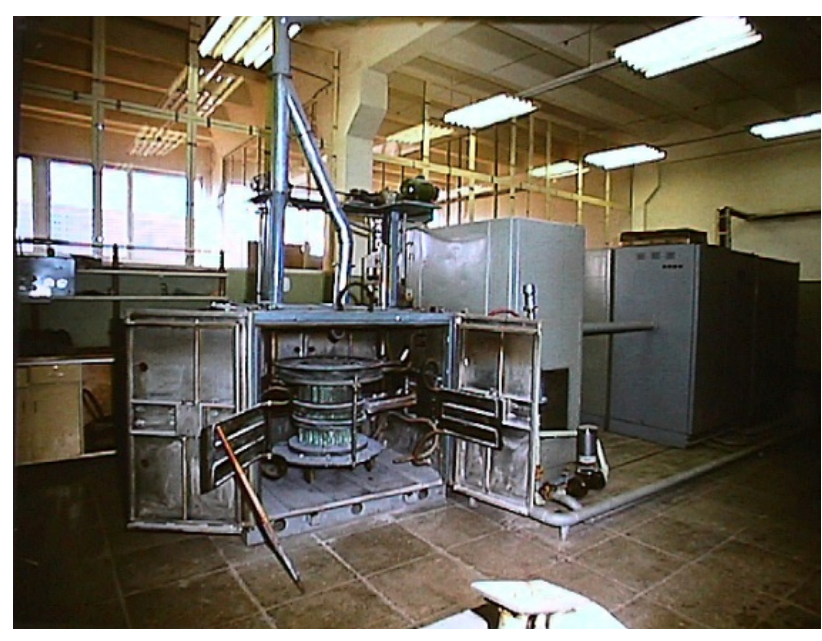

The "Kristall-403" installation (CC of $300 \mathrm{~mm}$ diameter)

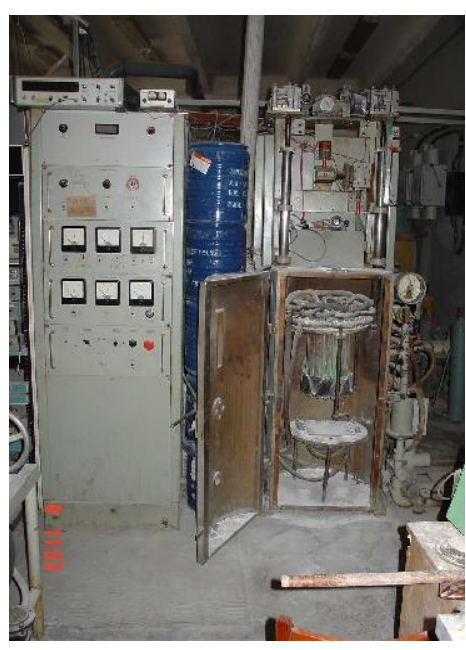

The "Kristall-401" installation

(CC of $180 \mathrm{~mm}$ diameter)

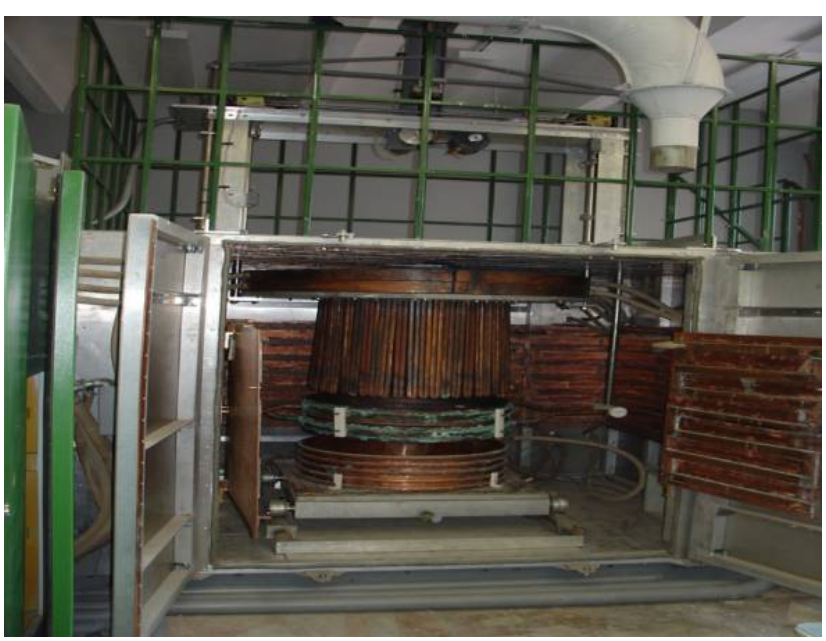

The "Kristall-403M" installation

(CC of $700 \mathrm{~mm}$ diameter) 


\section{Growth of the $\left(\mathrm{ZrO}_{2}\right)_{0.91-\mathrm{x}}\left(\mathrm{Sc}_{2} \mathrm{O}_{3}\right)_{0.09}\left(\mathrm{Yb}_{2} \mathrm{O}_{3}\right)_{\mathrm{x}}$ single crystals}

The compositions of the grown crystals and their symbols

\begin{tabular}{|c|c|}
\hline Compositions of the crystals & Symbol \\
\hline$\left(\mathrm{ZrO}_{2}\right)_{0.91}\left(\mathrm{Sc}_{2} \mathrm{O}_{3}\right)_{0.09}$ & $9 \mathrm{ScSZ}$ \\
\hline$\left(\mathrm{ZrO}_{2}\right)_{0.905}\left(\mathrm{Sc}_{2} \mathrm{O}_{3}\right)_{0.09}\left(\mathrm{Yb}_{2} \mathrm{O}_{3}\right)_{0.005}$ & $9 \mathrm{Sc} 0.5 \mathrm{YbSZ}$ \\
\hline$\left(\mathrm{ZrO}_{2}\right)_{0.90}\left(\mathrm{Sc}_{2} \mathrm{O}_{3}\right)_{0.09}\left(\mathrm{Yb}_{2} \mathrm{O}_{3}\right)_{0.01}$ & $9 \mathrm{Sc} 1 \mathrm{YbSZ}$ \\
\hline
\end{tabular}

Appearance of crystals

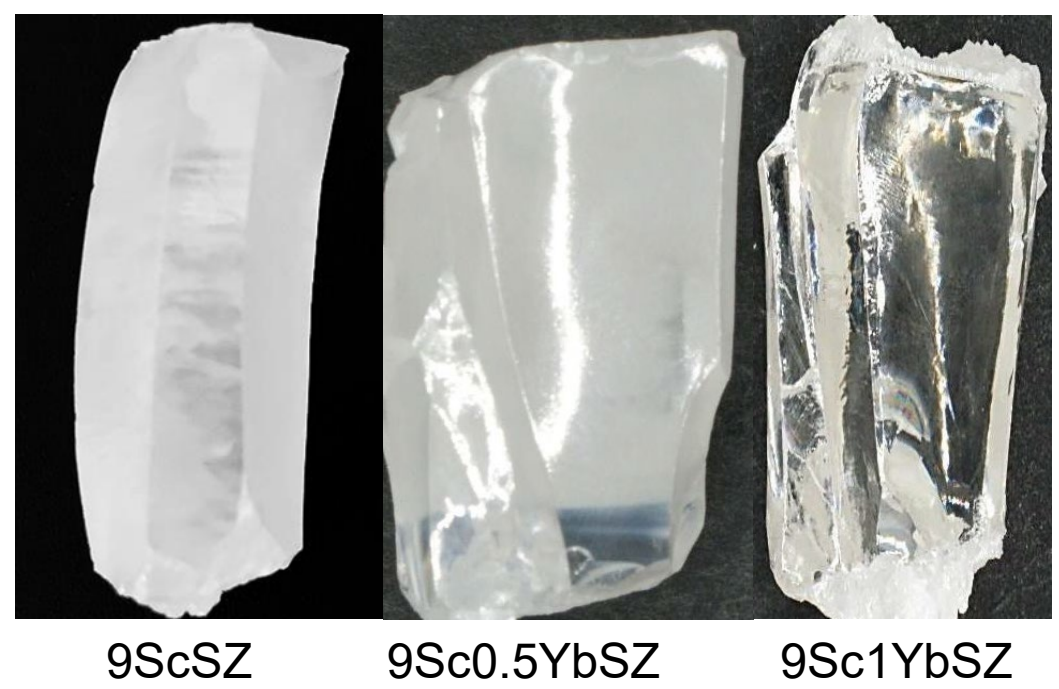

Images of the microstructure of crystals in polarized light

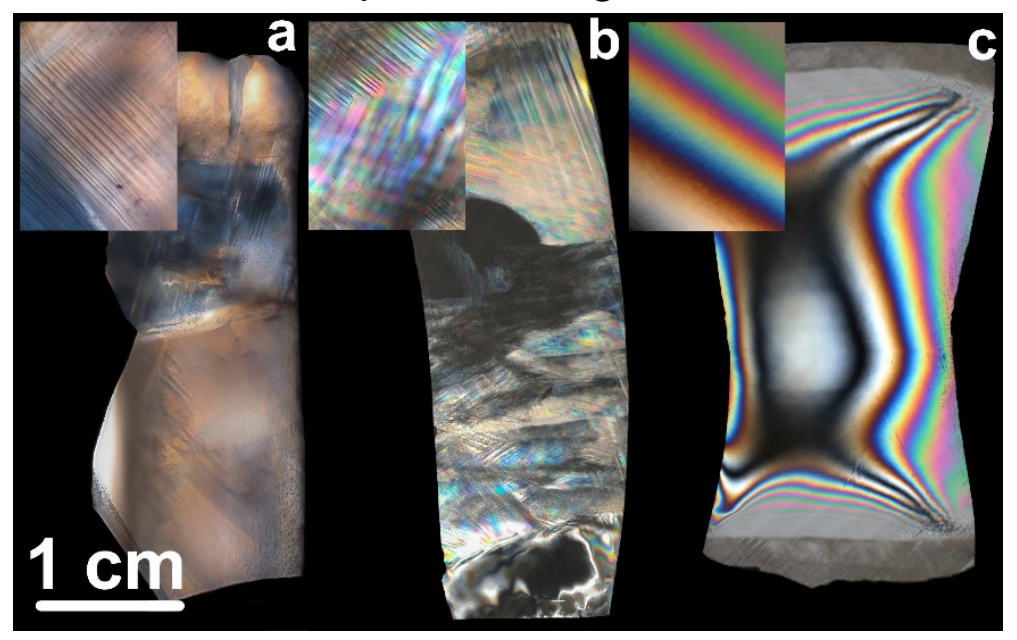

9ScSZ 9Sc0.5YbSZ 9Sc1YbSZ 


\section{Phase composition, density and lattice parameters for $\left(\mathrm{ZrO}_{2}\right)_{0.91-\mathrm{x}}\left(\mathrm{Sc}_{2} \mathrm{O}_{3}\right)_{0.09}\left(\mathrm{Yb}_{2} \mathrm{O}_{3}\right)_{\mathrm{x}}$ crystals}

The phase analysis of crystals was studied by X-ray diffractometry on plates cut from different parts of the crystal perpendicular to the $<100>$ direction.

\begin{tabular}{|c|c|c|c|c|c|c|}
\hline \multirow[b]{2}{*}{ Sample } & \multicolumn{3}{|c|}{ As-Grown } & \multicolumn{3}{|c|}{ As-Annealed, $1000^{\circ} \mathrm{C}$, 400 hours, air } \\
\hline & Phase & Lattice Parameters, $\mathrm{nm}$ & $\begin{array}{l}\text { Density, } \\
\text { g/cm3 }\end{array}$ & Phase & Lattice Parameters, nm & $\begin{array}{l}\text { Density, } \\
\text { g/cm3 }\end{array}$ \\
\hline 9ScSZ & $\mathrm{t}$ & $a=0.3595(1) ; c=0.5122(1)$ & $5.786(3)$ & $\begin{array}{l}\mathrm{t} \\
\mathrm{r}\end{array}$ & $\begin{array}{l}a=0.3596(1) ; c=0.5124(1) \\
a=0.3559(2) ; c=0.9007(2)\end{array}$ & $5.783(3)$ \\
\hline $9 S c 0.5 Y b S Z$ & $\begin{array}{l}\mathrm{t} \\
\mathrm{c}\end{array}$ & $\begin{array}{c}a=0.3597(1) ; c=0.5106(1) \\
a=0.5092(1)\end{array}$ & $5.816(3)$ & $\mathrm{t}$ & $a=0.3597(1) ; c=0.5110(1)$ & $5.818(3)$ \\
\hline 9Sc1YbSZ & C & $a=0.5094(1)$ & $5.863(3)$ & C & $a=0.5094(1)$ & $5.862(3)$ \\
\hline
\end{tabular}

$t$, c and $r$ - tetragonal, cubic and rhombohedral phases

Prolonged high-temperature annealing affects the phase composition and lattice parameters of the crystals. 


\section{Phase composition of the crystals before and after annealing}

The phase composition of the crystals was also studied by Raman scattering. This method makes it possible to reveal even insignificant changes in the local structure that occur in crystals during prolonged annealing.
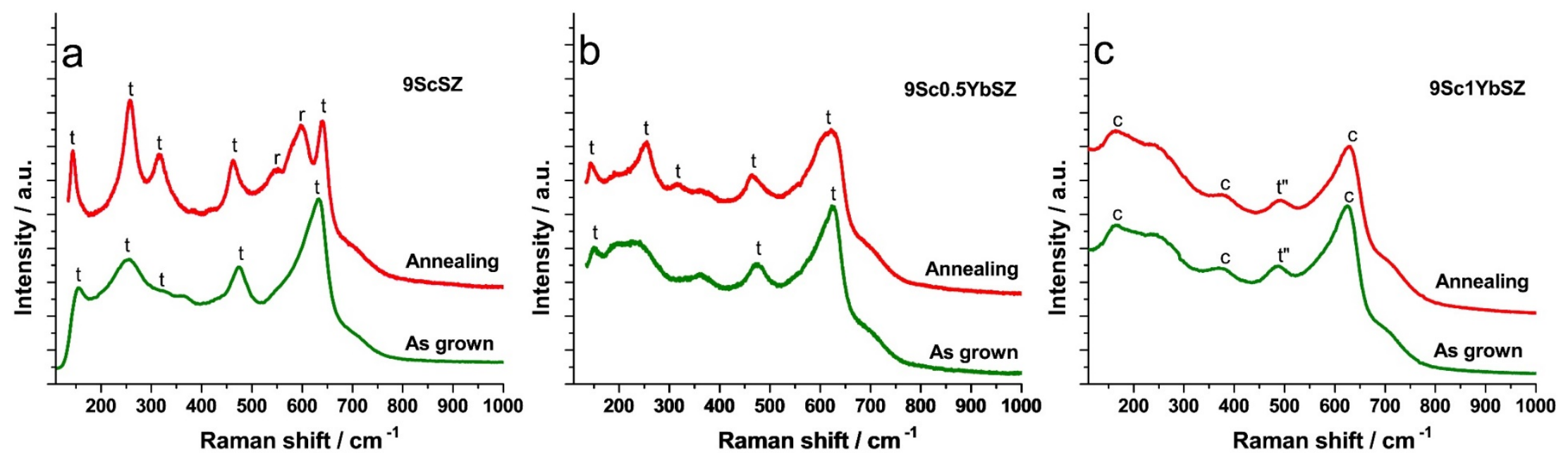

Codoping the $\mathrm{ZrO}_{2}-9$ mol\% $\mathrm{Sc}_{2} \mathrm{O}_{3}$ solid solution with ytterbium oxide at a concentration of $1 \mathrm{~mol} \%$ leads to the formation of single-phase crystals with a pseudocubic structure of the t"-phase, which is stable upon prolonged annealing in air. 


\section{Properties of the $\left(\mathrm{ZrO}_{2}\right)_{0.91-\mathrm{x}}\left(\mathrm{Sc}_{2} \mathrm{O}_{3}\right)_{0.09}\left(\mathrm{Yb}_{2} \mathrm{O}_{3}\right)_{\mathrm{x}}$ crystals}

The 9Sc1YbSZ crystals with a t"-phase structure have the maximum conductivity values over the entire temperature range.
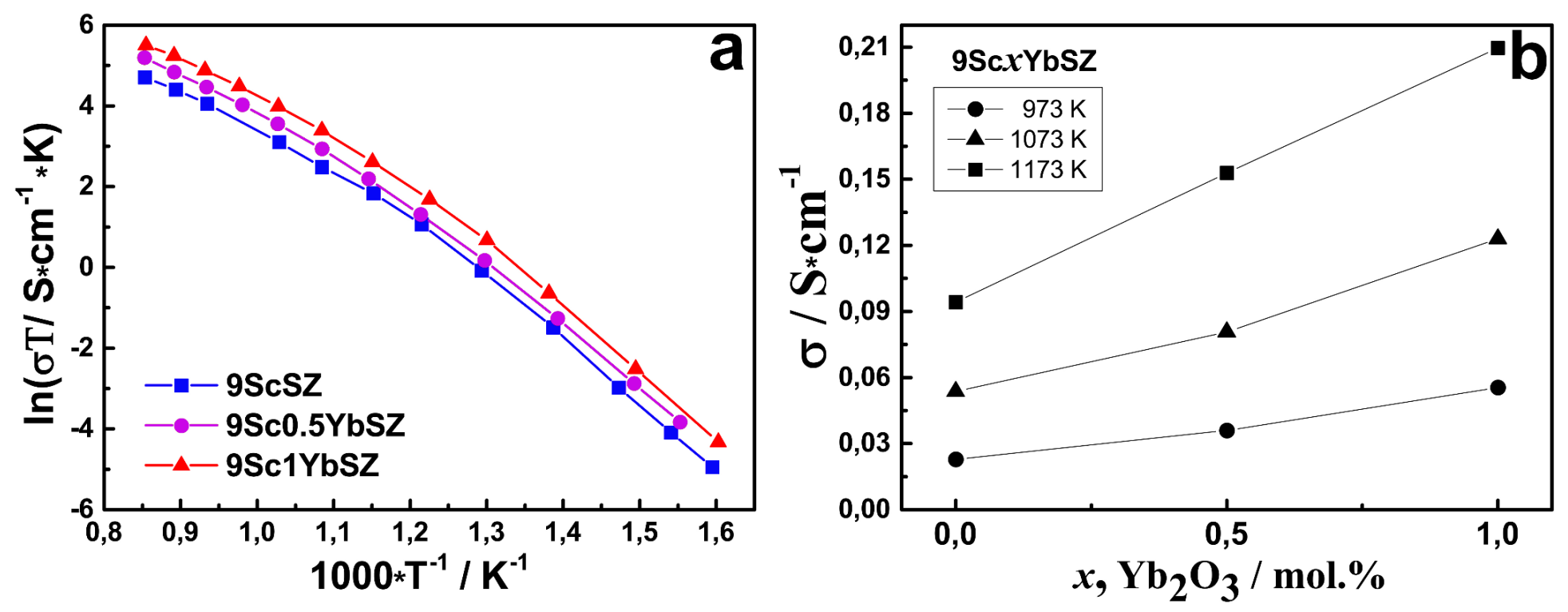

Temperature dependence of the conductivity of crystals in Arrhenius coordinates (a) and the conductivity of crystals depending on the concentration of $\mathrm{Yb}_{2} \mathrm{O}_{3}$ (b) 


\section{Properties of the $\left(\mathrm{ZrO}_{2}\right)_{0.91-\mathrm{x}}\left(\mathrm{Sc}_{2} \mathrm{O}_{3}\right)_{0.09}\left(\mathrm{Yb}_{2} \mathrm{O}_{3}\right)_{\mathrm{x}}$ crystals}

After annealing, the temperature dependence of the conductivity of the 9ScSZ crystal shows a jump in the conductivity in the temperature range of $\sim 600^{\circ} \mathrm{C}$, associated with the transition of the rhombohedral phase to the cubic. For the $9 \mathrm{Sc} 0.5 \mathrm{YbSZ}$ crystal, the values of the conductivity after annealing slightly decrease. For the $9 \mathrm{Sc} 1 \mathrm{YbSZ}$ crystal, the conductivity values before and after annealing practically coincide in the entire temperature range.
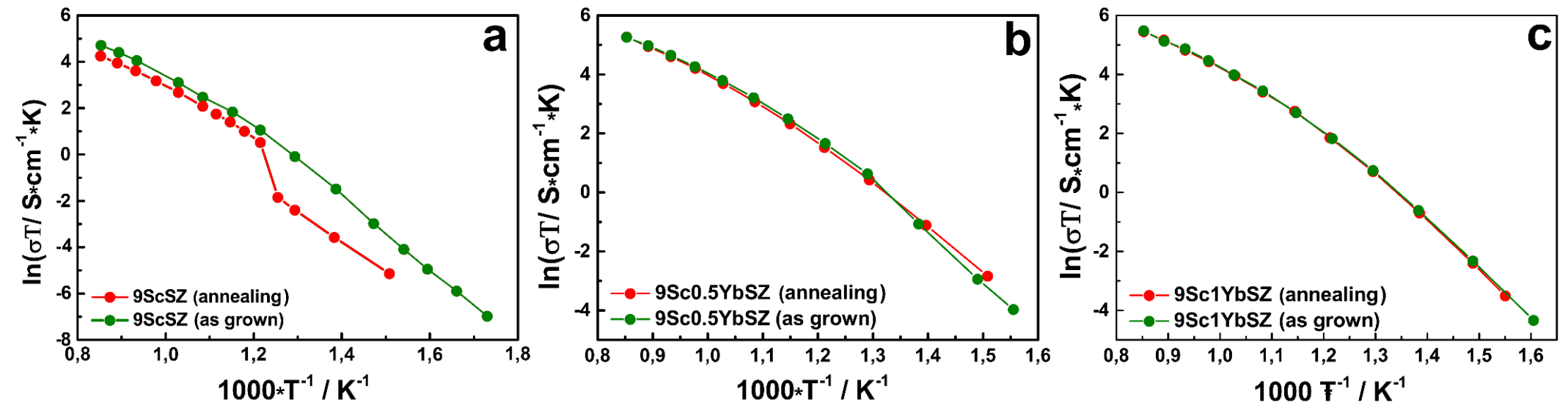

Temperature dependences of the conductivity of (a) 9ScSZ, (b) 9Sc0.5YbSZ, and (c) $9 S c 1 Y b S Z$ crystals before and after annealing. 


\section{Properties of the $\left(\mathrm{ZrO}_{2}\right)_{0.91-\mathrm{x}}\left(\mathrm{Sc}_{2} \mathrm{O}_{3}\right)_{0.09}\left(\mathrm{Yb}_{2} \mathrm{O}_{3}\right)_{\mathrm{x}}$ crystals}

After annealing in air at $1000^{\circ} \mathrm{C}$ for 400 hours, the conductivity at $1173 \mathrm{~K}$ of the 9ScSZ crystal decreases by $35 \%$. For the $9 \mathrm{Sc} 0.5 \mathrm{YbSZ}$ crystal, after annealing, the conductivity decreases by less than $10 \%$. For the $9 S c 1 Y b S Z$ crystal, no degradation of conductivity after annealing at $1000^{\circ} \mathrm{C}$ for 400 hours was observed.

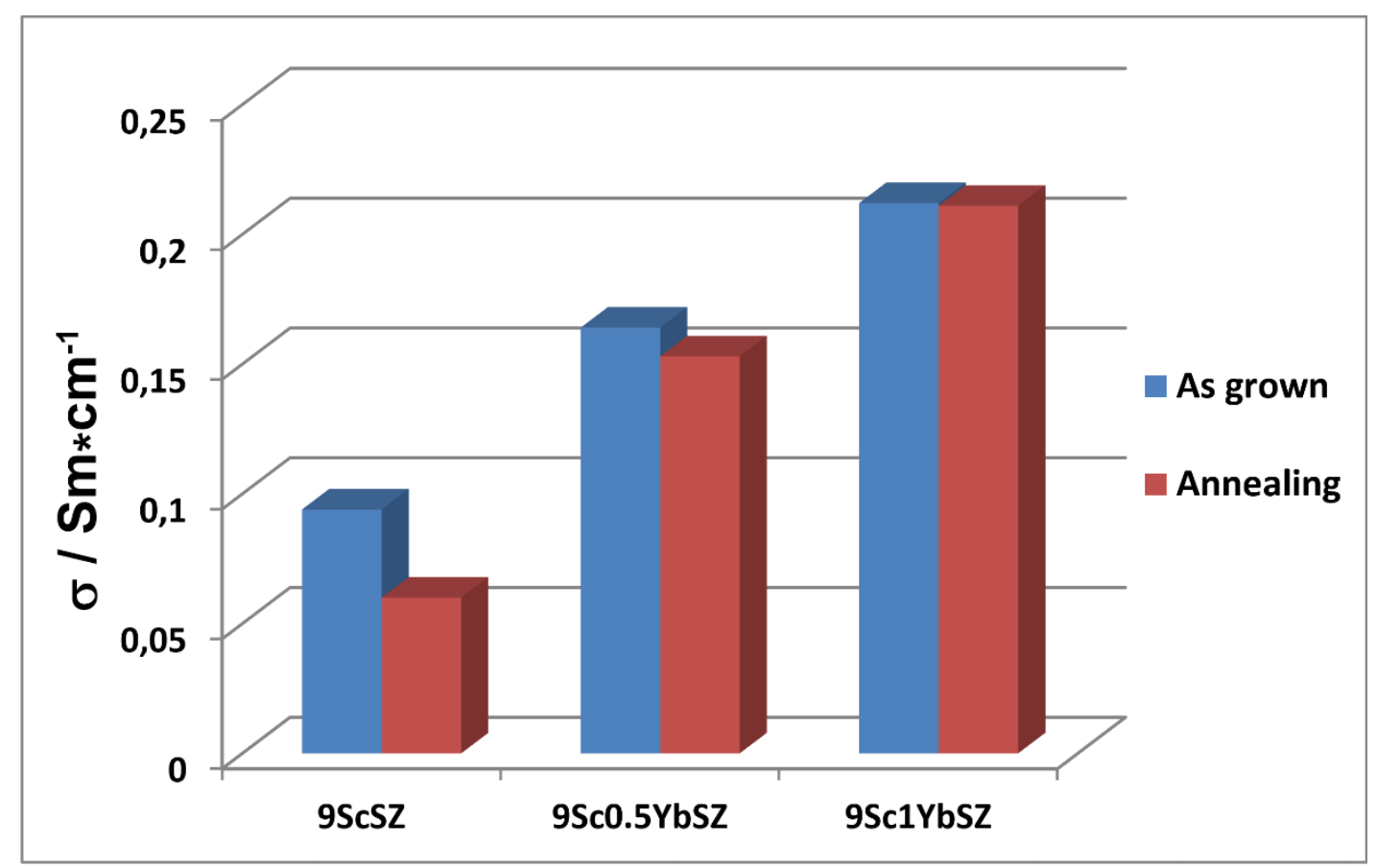

Conductivity values at $1173 \mathrm{~K}$ before and after annealing at $1000^{\circ} \mathrm{C}$ for 400 hours 


\section{Summary}

- It is shown that the stabilization of $\mathrm{ZrO}_{2}$ together with 9 mol.\% $\mathrm{Sc}_{2} \mathrm{O}_{3}$ and 1 mol.\% $\mathrm{Yb}_{2} \mathrm{O}_{3}$ makes it possible to obtain transparent homogeneous crystals with a pseudocubic structure, which have high phase stability.

- The conductivity of the crystals depending on the concentration of $\mathrm{Yb}_{2} \mathrm{O}_{3}$ is nonmonotonic.

- The $\left(\mathrm{ZrO}_{2}\right)_{0.9}\left(\mathrm{Sc}_{2} \mathrm{O}_{3}\right)_{0.09}\left(\mathrm{Yb}_{2} \mathrm{O}_{3}\right)_{0.01}$ crystals have a maximum conductivity in the investigated temperature range.

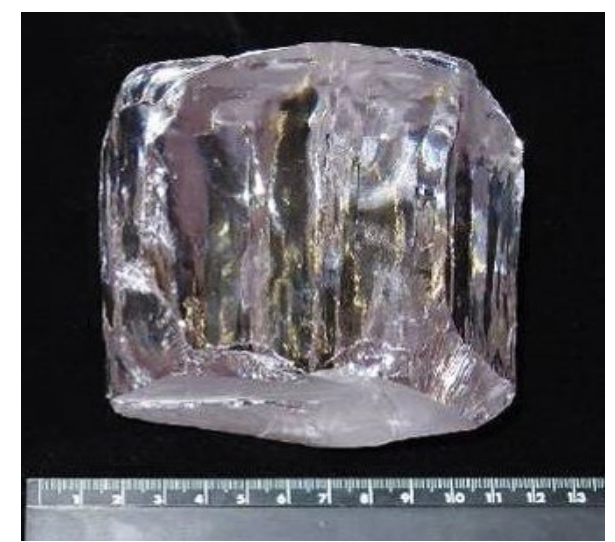

Single crystal based on zirconia

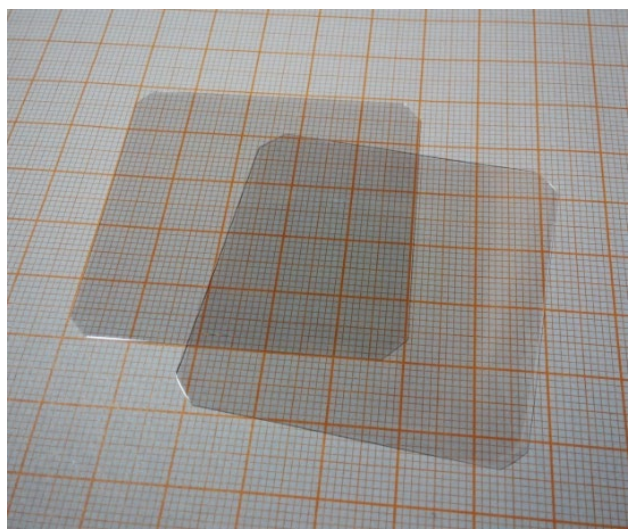

Single-crystal membranes (solid electrolyte).

The size of $50 \times 50 \mathrm{~mm}, h=200 \mu \mathrm{m}$

The work was carried out under financial support of the Russian Science Foundation (project № 19-72-10113). 